\title{
The Impact of Architectural Psychology on the Interior Design of Psychiatric Hospitals
}

\author{
Dr. Naglaa Ezzat Ahmed Mahmoud
}

Lecturer At Interior Design Department, Faculty of Applied Arts - 6th of October University, Egypt.

DOI: 10.21608/jdsaa.2021.29937.1043

\section{Keywords:}

Mental Health, Psychotherapy Hospitals, Architectural Psychology

\begin{abstract}
:
The World Health Organization (WHO) defines mental health as a state of physical, psychological and social comfort for the human being and not just the absence of the disease, and there is a growing need to study the spaces of psychiatric hospitals, but from the perspective of the comprehensive concept of correct architecture resulting from the use of environmental psychology and Architect when starting to design buildings and spaces so as to keep up with the requirements of the times such as the negative effects of digital technology, communication technology and industry on human beings.

Hence the idea of this research, which includes the study of the internal space of the psychiatric hospital by architectural psychology where the void with all its elements and components can affect the positive or negative on the patients.
\end{abstract}

\section{- Introduction:}

Public health (physical and psychological) is one of the foundations of human wealth, on which the nation's structure is based, and mental health is of great importance, perhaps exceeding the importance of physical health because it affects it directly and indirectly, and the external and internal environment affects therapeutic spaces with all the elements it contains on Psychopaths have a negative or positive attitude and here comes the role of the interior designer in providing a correct treatment environment that positively affects the patient's health and contributes well and correctly to the treatment process.

In an attempt to achieve the goal of research and access to a correct internal therapeutic vacuum, it affects positively the user's health of psychopaths, especially in medical residency spaces, the research was conducted in two axes:

The first axis: mental health and psychiatric hospital. The second axis: Architectural Psychology (man and space).

\section{- Research Goals and Importance:}

Upgrading the design level and the level of performance of the space, and thus the level of health care in the Psychiatric Hospital, by applying the foundations of architectural psychology when designing the interior spaces for treatment accommodation spaces.

\section{- Research Methodology:}

Descriptive analytical method

1. Mental health and psychiatric hospital

Mental health is linked to the quality of life and productivity because of its direct impact on physical health, and the term mental health is one of the most overburdened terms of reactionary ideas, especially in our developing societies.

\subsection{Mental health:}

Know that it is a state of safety and wellness through which the individual realizes his potential and abilities and is able to adapt to the adversity and psychological pressures natural and be able to work productively, share and contribute to society. (1)

Dr. Hamed Zahran has provided another definition of 
mental health more comprehensive and detailed that it is a relative situation in which the individual is psychologically compatible (personally, emotionally and socially with himself and environment) and feels happy with others and is able to achieve himself and exploit his abilities and able to face life personally Integrated together with a healthy behavior and good creation, it is a positive condition that includes the enjoyment of mental health and the integrity of behavior. (2)

1.2. Goals and importance of mental health:

Due to its association with the productivity of the individual and its abilities, adaptation and contribution to society, it represents an important pillar unfortunately overlooked by many, mental health problems affect the family fundamentally and therefore affect the society as a whole (3), and summarizes the following scheme (chart (1)goals and importance of mental health).

\subsection{Psychiatry:}

It is that medical specialty that is concerned with the study and treatment of mental and behavioral function disorder by providing preventive, therapeutic and rehabilitative mental health care or what is known as psychiatric medical services (4) .

\subsubsection{Mental illness :}

It is known as a functional personality disorder (5) that appears in the form of different psychological and physical symptoms and affects the behavior of the person, which hinders him from practicing his normal life and psychological compatibility, and the treatment of the disease depends on the type and extent of his severity and on the person and the nature of his personality (2).
In fact, there are no reliable statistics in Egypt in the field of psychiatric diseases, as in some organic diseases, but statistical information depends on research, which in turn depends on samples, no matter how large they are, they are small in relation to the population and do not reflect the societal reality of mental illness, and returns this is due to many reasons, including the fact that society does not recognize most of its different levels of mental illness, fear or shyness from this recognition, and this is because of traditions that classify any disease or symptoms of a disease as a state of insanity that no one should know about.

And psychological diseases are many and widespread and more in the number of industrial cities crowded and capitalized from the suburbs and quiet places and mental diseases many reasons where the relations affect since childhood between parents and between the child and parents and brothers in the surroundings of the small family or in the surroundings of other relatives in the family as The school also has a role (family and social relations in general), in addition to community events, customs, traditions and religious values, and the causes of mental illness are summarized to three reasons: vital, psychological and environmental causes individually, bilaterally or interactively.

There are many classifications of mental diseases, the most important of which is the classification, which is based on the study of the causes and the nature of the pathological change that it creates, in which the mental diseases are divided into four main types under which other subtvnes are included in the Table (1).

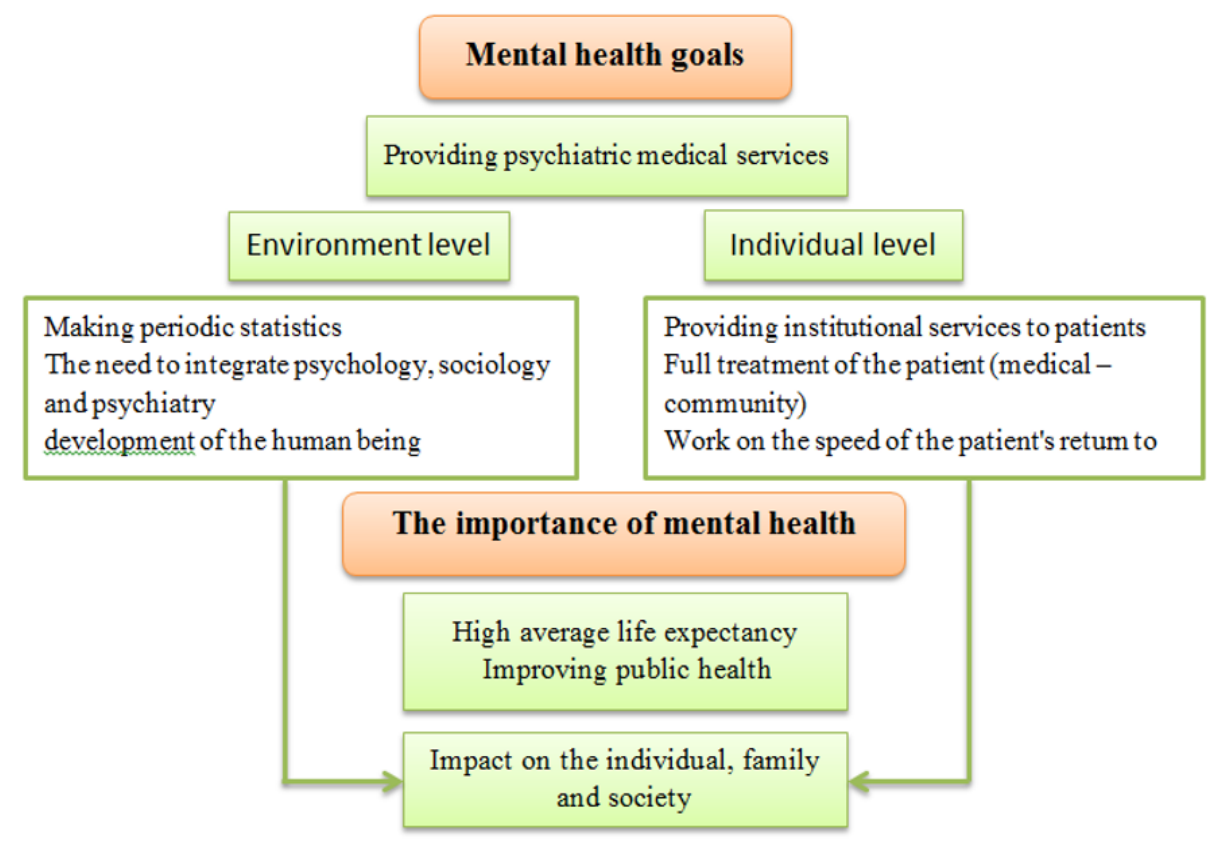

Chart (1) Goals and importance of mental health. (1) and (3) (Designed by researcher) 


\begin{tabular}{|c|c|c|c|}
\hline \multicolumn{4}{|c|}{ Types of mental illnesses } \\
\hline Personal disorders & $\begin{array}{l}\text { Physical mental } \\
\text { disorders }\end{array}$ & $\begin{array}{l}\text { Neurological } \\
\text { diseases } \\
\text { (neurosis) }\end{array}$ & $\begin{array}{l}\text { Mental illness } \\
\text { (psychosis) }\end{array}$ \\
\hline Organic disorders & \multirow{6}{*}{$\begin{array}{l}\text { Disorders of the organs } \\
\text { of the body } \\
\text { Nervous, periodic, } \\
\text { reproductive, glands... } \\
\text { And so on }\end{array}$} & Concern & Schizophrenia \\
\hline $\begin{array}{l}\text { Delay and mental } \\
\text { impairment }\end{array}$ & & Depression & Mania \\
\hline Addiction & & Histria & \multirow[t]{4}{*}{ Paranoia } \\
\hline Sexual deviation & & Disintegration & \\
\hline $\begin{array}{l}\text { Marriage, youth and } \\
\text { old age problems }\end{array}$ & & \multirow[t]{2}{*}{ Compulsive wasass } & \\
\hline Disabled problems & & & \\
\hline
\end{tabular}

Table (1) Some types of psychiatric diseases (2) (Designed by researcher)

The diagnosis of mental illness is an important process where it is the way to identify the origin, nature and type of disease, through which the appropriate treatment method is determined, which is a complex process resulting from a thorough examination process that includes a thorough examination organized for the patient and includes a local physical medical examination or devices for the organs of the body and Psychological examination, which is carried out in many ways, including interviewing, observation and case study, in addition to the use of tests and measurements, the three processes of examination, diagnosis and treatment are successive continuous processes.

In order to achieve psychotherapy and access to healing, it is necessary to create a spatial environment (psychiatric hospital - psychiatric centers) that provides security, understanding and acceptance of the patient and behavior as well as providing doctors and staff a safe atmosphere to help do the work and hence the psychological therapeutic facility can be defined as The facility provides all diagnostic, therapeutic, rehabilitative and preventive mental health care services for psychiatric patients.

Hospitals and medical and psychological treatment centers are considered one of the most complex public buildings and the most expensive and the society needs them most because they must meet the different functional needs of diagnosis, treatment and prevention while achieving human needs and providing security and safety to patients and For doctors, nurses and administrators ... And others.

The concept of designing and building hospitals and psychotherapy centers has changed to suit the developments of era. The psychiatric hospital is no longer a building isolated from the environment and filled with patients who were separated as a result of the building's isolation from their external reality, but rather it became a building open to the environment and connected to it and Interact with it internally and externally designed in a manner that meets all functional and human needs in aesthetic frameworks studied and contributes to helping the patient to overcome the difficulties of the disease and then speed and effectiveness of treatment so that it returns to the community train quickly.

In fact, when initiating the interior design of the psychiatric hospital, a thorough study of a range of factors affecting the design style and details of the design should be carried out:

-Study the environmental, geographical and climatic factors of the area where the building is built.

-Studying the cultural, social and economic factors of the region's population.

-Study the impact of the environment, heritages, customs, traditions and religion.

-An overview of mental illnesses in general and the most common diseases in the region.

-Study the problems of psychotherapy (especially long-term treatment) and the method of treating patients and managing their lives in the hospital (where there are some psychiatric conditions that may continue to be treated for years).

- Classification of patients for groups according to the type of disease, severity, methods of treatment and duration and place of treatment.

1.3.2. The void elements of the psychiatric hospital:

The choice of the appropriate location for the building represents the first pillar of access to a good and correct design that can achieve and function, providing the right environment for hospitalization and medical work requires the selection of a well-thought-out lo- 
cation in many respects must be relatively isolated from external noise and acoustic and visual pollution and antenna (Away from airports, factories, trains and commercial centers), as it must be connected and close to transportation routes for easy transportation, and must provide privacy, safety and safety for patients and workers, and the reception area is the central area through which easy access To all the spaces of the hospital and therefore must be clear and distinctive design and can reach the two main departments of the hospital, namely the department of treatment services and the department of nursing units and falls under them all the subspaces that make up the parts of the hospital, and shows the plan (3) the relationships between the elements of the vacuum To the hospital.

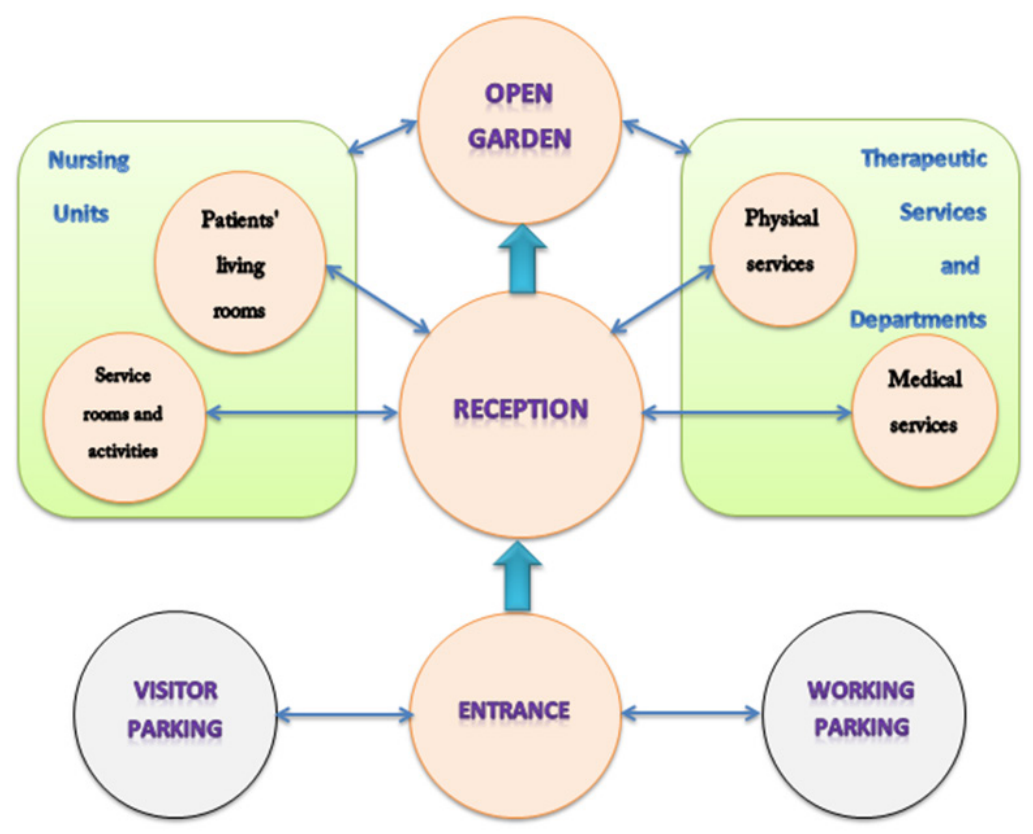

Chart (2) the void elements of the psychiatric hospital. (Designed by researcher)

1.3.3 Functional components of psychiatric hospital vacuums:

Each space of the psychiatric hospital has a specific function with specifications and criteria and the hospital is divided into two main sections, namely the department of therapeutic services and the department of nursing units must reach both from the reception area and the following table shows the vacuum components and standards and specifications that must be Available in order to achieve the desired job or functions as it shows the different relationships between functions for spaces:

\begin{tabular}{|c|c|c|c|c|}
\hline Vacuum & Ingredients & $\begin{array}{ll}\begin{array}{l}\text { Standards } \\
\text { specifications }\end{array} & \text { and }\end{array}$ & \multicolumn{2}{|l|}{ Relations } \\
\hline $\begin{array}{l}\text { The } \\
\text { entrance }\end{array}$ & $\begin{array}{l}\text { Entry and exit d oors - } \\
\text { signs }\end{array}$ & $\begin{array}{l}\text { Clear and easy to reach from } \\
\text { the outside on foot/movement } \\
\text { of the disabled/cars }\end{array}$ & \multicolumn{2}{|c|}{$\begin{array}{l}\text { Direct relationship with } \\
\text { reception/parking/external entrance }\end{array}$} \\
\hline \multirow[t]{4}{*}{$\begin{array}{l}\text { Reception } \\
\text { hall }\end{array}$} & Counter & $\begin{array}{l}\text { Clear and distinctive } \\
\text { design/sufficient depending on } \\
\text { the number of beds }\end{array}$ & & \multirow{4}{*}{$\begin{array}{l}\text { Strong } \\
\text { direct } \\
\text { relationship } \\
\text { with t he } \\
\text { portal/all } \\
\text { spaces }\end{array}$} \\
\hline & $\begin{array}{l}\text { Patient } r \text { egistration and } \\
\text { admission room }\end{array}$ & $\begin{array}{l}\text { Office/place to graduate } \\
\text { files/patient interviews }\end{array}$ & $\begin{array}{l}\text { Indirect relationship } \\
\text { with the medical } \\
\text { service area } \\
\text { (diagnostic clinic) }\end{array}$ & \\
\hline & $\begin{array}{l}\text { Waiting a } \\
\text { +Bathrooms }\end{array}$ & $\begin{array}{l}\text { A character that attracts the } \\
\text { patient and removes the initial } \\
\text { monastic ity of the } \\
\text { place/single part and the other } \\
\text { in the form of salons }\end{array}$ & & \\
\hline & A place to sell fast drinks & Optional and quality increases & Side space adjacent $\mathrm{t}$ & \\
\hline
\end{tabular}




\begin{tabular}{|c|c|c|c|c|c|}
\hline & & & $\begin{array}{l}\text { the familiarity and inability } \\
\text { between the patient and the } \\
\text { place of treatment }\end{array}$ & parking lots & \\
\hline \multirow[t]{2}{*}{$\begin{array}{l}\text { Motion } \\
\text { paths }\end{array}$} & \multicolumn{2}{|c|}{ Horizontal } & $\begin{array}{l}\text { Clear/avoid long, wide- } \\
\text { bend/wide corridor for two } \\
\text { people/use of illuminated } \\
\text { signage }\end{array}$ & $\begin{array}{l}\text { Clear network } \\
\text { relationships to easily } \\
\text { lead to all the spaces }\end{array}$ & \multirow{2}{*}{$\begin{array}{l}\text { Easy and } \\
\text { quick } \\
\text { access to } \\
\text { any } \\
\text { vacuum }\end{array}$} \\
\hline & Vertical & & $\begin{array}{l}\text { The presence of the stairs in a } \\
\text { suitable and clear place/the } \\
\text { absence of a stair well }\end{array}$ & $\begin{array}{l}\text { Direct connection to } \\
\text { all floors }\end{array}$ & \\
\hline \multirow[t]{2}{*}{$\begin{array}{l}\text { Nursing } \\
\text { units }\end{array}$} & \multirow[t]{2}{*}{$\begin{array}{l}\text { Patients' } \\
\text { rooms }\end{array}$} & $\begin{array}{l}\text { Individual/bil } \\
\text { ateral }+ \\
\text { bathroom in } \\
\text { the room }\end{array}$ & $\begin{array}{l}\text { Interior design: Simple home- } \\
\text { like comfort and privacy under } \\
\text { surveillance and safety } \\
\text { requirements for dangerous } \\
\text { and violent } \\
\text { situations/providing an } \\
\text { isolation room for every } 20 \\
\text { beds } \\
\text { Furniture: bed, cupboard, } \\
\text { writing table and seat/sofa } \\
\text { open bed in some rooms for } \\
\text { facilities/TV }\end{array}$ & \multirow[t]{2}{*}{$\begin{array}{l}\text { A little isolated from } \\
\text { reception and medical } \\
\text { services. } \\
\text { In direct contact with } \\
\text { the outer garden }\end{array}$} & \multirow{2}{*}{$\begin{array}{l}\text { Each } \\
\text { department } \\
\text { has its own } \\
\text { reception, } \\
\text { which is in } \\
\text { direct } \\
\text { contact } \\
\text { with the } \\
\text { general } \\
\text { reception } \\
\text { and the } \\
\text { therapeutic } \\
\text { services } \\
\text { department. }\end{array}$} \\
\hline & & $\begin{array}{l}\text { Wards }+ \\
\text { bathroom }\end{array}$ & $\begin{array}{l}4: 10 \text { beds with separated } \\
\text { curtains or vertical stubs for } \\
\text { privacy/have a large bathroom } \\
\text { attached }\end{array}$ & & \\
\hline Vacuum & \multicolumn{2}{|c|}{ Ingredients } & $\begin{array}{l}\text { Standards and } \\
\text { specifications }\end{array}$ & \multicolumn{2}{|l|}{ Relations } \\
\hline \multirow[t]{7}{*}{$\begin{array}{l}\text { Nursing } \\
\text { units }\end{array}$} & \multirow[t]{7}{*}{$\begin{array}{l}\text { Various } \\
\text { activity } \\
\text { rooms } \\
\text { and } \\
\text { services }\end{array}$} & Living Room & $\begin{array}{l}\text { Designed in a home-like way } \\
\text { to achieve an atmosphere of } \\
\text { familiarity, containment and } \\
\text { security/contains a } \\
\text { comfortable sofa by } \\
\text { family/TV/radio or music } \\
\text { player/magazines }\end{array}$ & $\begin{array}{l}\text { In direct contact with } \\
\text { rooms and wards. }\end{array}$ & \multirow{7}{*}{$\begin{array}{l}\text { Each } \\
\text { department } \\
\text { has its own } \\
\text { reception, } \\
\text { which is in } \\
\text { direct } \\
\text { contact } \\
\text { with the } \\
\text { general } \\
\text { reception } \\
\text { and the } \\
\text { therapeutic } \\
\text { services } \\
\text { department. }\end{array}$} \\
\hline & & Dining Hall & $\begin{array}{l}\text { Accommodates all } \\
\text { patients/traffic } \\
\text { corridors/tables, benches and } \\
\text { beverage counters with safe } \\
\text { design for dangerous and } \\
\text { violent situations }\end{array}$ & $\begin{array}{l}\text { In indirect relationship } \\
\text { with the rooms, the } \\
\text { wards and the dining } \\
\text { hall. }\end{array}$ & \\
\hline & & $\begin{array}{l}\text { Interview \& } \\
\text { meeting } \\
\text { room }\end{array}$ & $\begin{array}{l}\text { Used to meet patients with } \\
\text { their parents }\end{array}$ & \multirow[b]{2}{*}{ They can be merged. } & \\
\hline & & $\begin{array}{l}\text { Therapeutic } \\
\text { meeting room }\end{array}$ & $\begin{array}{l}\text { From } 10: 12 \\
\text { people/comfortable seats/used } \\
\text { for treatment and } \\
\text { rehabilitation }\end{array}$ & & \\
\hline & & $\begin{array}{l}\text { Nursing } \\
\text { station }\end{array}$ & $\begin{array}{l}\text { Central location for easy } \\
\text { follow-up and access to all } \\
\text { parts of the suite }\end{array}$ & \multirow{3}{*}{$\begin{array}{l}\text { In direct contact with } \\
\text { the rooms. }\end{array}$} & \\
\hline & & $\begin{array}{l}\text { Nursing } \\
\text { station } \\
\text { management }\end{array}$ & $\begin{array}{l}\text { Room to follow up the } \\
\text { patient's residence/nursing } \\
\text { station/record and store the } \\
\text { patient's medical reports }\end{array}$ & & \\
\hline & & $\begin{array}{l}\text { Doctor's } \\
\text { room }+ \\
\text { doctor's room }\end{array}$ & $\begin{array}{l}\text { To follow up on the } \\
\text { performance of the nursing } \\
\text { station/responsible for the }\end{array}$ & & \\
\hline
\end{tabular}




\begin{tabular}{|c|c|c|c|c|c|}
\hline & & & entire ward & & \\
\hline & & $\begin{array}{l}\text { Services: } \\
\text { Laundry/Clea } \\
\text { ner/Bathroom } \\
\text { s/Stores }\end{array}$ & $\begin{array}{l}\text { Taking into account health and } \\
\text { safety requirements in sanitary } \\
\text { buildings }\end{array}$ & & \\
\hline \multirow[t]{5}{*}{$\begin{array}{l}\text { Therapeuti } \\
\text { c services } \\
\text { and } \\
\text { services }\end{array}$} & \multirow[t]{5}{*}{$\begin{array}{l}\text { Medical } \\
\text { treatment } \\
\text { services }\end{array}$} & $\begin{array}{l}\text { treatment } \\
\text { With } \\
\text { electric } \\
\text { shocks }\end{array}$ & $\begin{array}{l}\text { Reception/waiting/equipped } \\
\text { treatment } \\
\text { rooms/dormitory/doctors and } \\
\text { nursing }\end{array}$ & Isolated & \\
\hline & & $\begin{array}{l}\text { Outpatient } \\
\text { clinic }\end{array}$ & $\begin{array}{l}\text { Detection and diagnosis of the } \\
\text { disease for the frequent/simple } \\
\text { design reception/wait/nursing } \\
\text { station/screening } \\
\text { rooms/treatment } \\
\text { rooms/bathrooms/stores/clean } \\
\text { er }\end{array}$ & $\begin{array}{l}\text { It could have a special } \\
\text { exterior entrance from } \\
\text { the garden. }\end{array}$ & \\
\hline & & Pharmacy & \multirow{3}{*}{$\begin{array}{l}\text { Equipment according to } \\
\text { psychiatric requirements and } \\
\text { number of beds }\end{array}$} & \multirow{3}{*}{$\begin{array}{l}\text { Indirect relationship } \\
\text { with the public } \\
\text { reception }\end{array}$} & \\
\hline & & X-rays & & & \\
\hline & & Labs & & & \\
\hline Vacuum & \multicolumn{2}{|c|}{ Ingredients } & $\begin{array}{l}\text { Standards } \\
\text { specifications }\end{array}$ & \multicolumn{2}{|l|}{ Relations } \\
\hline \multirow{10}{*}{$\begin{array}{l}\text { Services } \\
\text { and } \\
\text { The } \\
\text { medical } \\
\text { departmen } \\
\text { ts }\end{array}$} & \multirow[t]{8}{*}{$\begin{array}{l}\text { Departm } \\
\text { ent of } \\
\text { Physical } \\
\text { Rehabilit } \\
\text { ation }\end{array}$} & $\begin{array}{l}\text { Special } \\
\text { reception }\end{array}$ & $\begin{array}{l}\text { In addition, the government's } \\
\text { commitment to the "right to } \\
\text { self-government" is a key } \\
\text { factor in the country's } \\
\text { economic and social stake. }\end{array}$ & $\begin{array}{l}\text { An isolated } \\
\text { relationship from the } \\
\text { public reception }\end{array}$ & \multirow{10}{*}{$\begin{array}{l}\text { has a } \\
\text { special } \\
\text { reception } \\
\text { and in a } \\
\text { relationship } \\
\text { isolated } \\
\text { from the } \\
\text { public } \\
\text { reception }\end{array}$} \\
\hline & & $\begin{array}{l}\text { Organic } \\
\text { physical } \\
\text { therapy }\end{array}$ & \multirow{7}{*}{$\begin{array}{l}\text { Equipment according to the } \\
\text { general requirements of each } \\
\text { activity and according to the } \\
\text { medical and psychological } \\
\text { requirements } \\
\text { And the number of beds. }\end{array}$} & \multirow{3}{*}{ Presence is required } & \\
\hline & & Massage & & & \\
\hline & & $\begin{array}{l}\text { Physical } \\
\text { exercises }\end{array}$ & & & \\
\hline & & $\begin{array}{l}\text { Therapeutic } \\
\text { swimming } \\
\text { pool }\end{array}$ & & \multirow{4}{*}{$\begin{array}{l}\text { Specialized treatments } \\
\text { may be required by the } \\
\text { treatment program and } \\
\text { are not required to be } \\
\text { present in all hospitals }\end{array}$} & \\
\hline & & $\begin{array}{l}\text { Thermal } \\
\text { enforcement }\end{array}$ & & & \\
\hline & & Ultrasound & & & \\
\hline & & $\begin{array}{l}\text { Mud baths / } \\
\text { wax / sulfur } \\
\text { water }\end{array}$ & & & \\
\hline & \multirow[t]{2}{*}{$\begin{array}{l}\text { Departm } \\
\text { ent of } \\
\text { Recreatio } \\
\text { nal } \\
\text { Therapeu } \\
\text { tic } \\
\text { Services }\end{array}$} & $\begin{array}{l}\text { Recreational } \\
\text { treatment } \\
\text { Rooms for } \\
\text { hobbies/drawi } \\
\text { ng/music }\end{array}$ & $\begin{array}{l}\text { Equipment according to the } \\
\text { general requirements of each } \\
\text { activity and according to the } \\
\text { medical and psychological } \\
\text { requirements } \\
\text { And the number of } \\
\text { beds/proper interior design } \\
\text { contributes to the speed of } \\
\text { healing }\end{array}$ & \multirow[t]{2}{*}{$\begin{array}{l}\text { An isolated } \\
\text { relationship from the } \\
\text { public reception }\end{array}$} & \\
\hline & & $\begin{array}{l}\text { Bathrooms } \\
\text { and stores }\end{array}$ & Tool keeper/cleaner & & \\
\hline
\end{tabular}

Table (2) The functional components of psychiatric hospital spaces, their requirements and the relations between them (6) and (7) (Designed by researcher) 


\section{Architectural Psychology (Man and Space)}

\subsection{Environmental Psychology:}

It is a science that studies the interactive relationship between man and the environment (in general) it is interested in studying all the mutual effects between the elements and details of the physical environment (shape, color, light, climate and plant.... It also examines the impact of environmental factors on mental health and production efficiency, which helps to provide solutions to psychological and social problems resulting from the physical and social environment conditions. (8)

There are many theories based on the principles of environmental psychology, whose goal is to preserve human health:

- The theory of excitement (environment is a positive or negative catalyst).

- Environment and man are one entity.

- The environment is controlled by man.

- Continuous interaction between the environment and man.

But the researchers in this field believe that these theories do not work individually but work together and that to reach a correct environment, especially in the architecture and internal spaces where the human lives of more than $80 \%$ of his life, and when looking at the psychiatric hospital as an internal environment we find that it must be positively stimulating and avaful Constantly bug with the human and meet his needs until they become one entity. (9) and (10)

2.2. Architectural Psychology:

It is one of the branches of environmental psychology and it is the science interested in studying the impact of the built environment and architecture and the impact of internal and external voids on people who use space, in terms of knowledge, social and emotional, in order to reach the architectural design of the correct and healthy buildings that support the user in terms of Physical, social and psychological.

Architectural psychology is based on the study of the relationship between man and space. There is a network of complex reciprocal relations between man and the internal vacuum. The bilateral mutual interaction between them is continuous. The vacuum with all elements and components (material, social and psychological) affects the person and adds to him and affects the human being. On the void and adds to it and pigmentation with an identity, and from here we come to the void with a personal identity, as a result of this because architectural psychology deals with the psy- chological processes of interaction between man and all the vocabulary of the internal void such as cognition, thinking, behavior and requirements of living. The vacuum derives its qualities from its elements and relations between them and the way the way the human mind perceives it and the psychological composition of users, especially in the spaces of treatment and residence in the psychiatric hospital and from those reciprocal relationships create a dialogue between the void and the human in this case the language of dialogue must be clear and understandable In order to be able to deal with the patient with the vacuum and be able to reach the stage of healing, the internal spaces of the hospital must achieve a set of concepts, which represent the vocabulary of the language of continuous dialogue complex between them and the user and that in order to reach the patient for the stage of healing, which is the main purpose. (Chart 3) explains vocabulary of the language of mutual dialogue and the way in which the human being perceives it to the void of personal identity. (14)

2.3. Cognitive process:

It is an attempt to understand the world around us by interpreting the information coming from the senses to the human brain, and understanding here includes interpretation, coding, analysis, storage and response. (17) It is a means of communication and a link between vacuum and user (patient) to reach the creation of language of space between them patient's sense of emptiness is the result of the process of perception that deals with the data of the environment surrounding all its elements and then affects his mind and the process of absorption of the vacuum or what is known By understanding the vacuum that leads to the mutual effect between patient and vacuum using the language of the previous dialogue between them, and the process of perception and assimilation is a complex dual process, a complex mental process, physical and emotional, is carried out through the five senses of man (awareness of sensory stimuli), each sense is responsible for the perception and absorption of part of the vacuum The eye is responsible for the sense the visual sense, which performs the process of visual perception and is responsible for the partial perception of the form and then the perception of the forms and relationships between them and thus the total perception of the shape of the void and its forms and relationships and

in the same way is responsible for the perception of colors and light other elements such as water and 
plants .... And others. The following chart (4) illustrates the cognitive process through the senses, which are key to the treatment of mental illness. (18)

\section{The vacuum language and its effect on the user}

\begin{tabular}{|c|c|c|c|}
\hline & Communication & $\begin{array}{l}\text { Communication through clear spatial division is relationships in } \\
\text { direct geometric forms away from highly bending or refractive } \\
\text { lines with the nce of indirarive markers }\end{array}$ & $\begin{array}{l}\text { Communication gives the } \\
\text { patient a sense of place, privacy } \\
\text { and colf.mnfirdence }\end{array}$ \\
\hline & $\begin{array}{l}\text { Flow } \\
\text { Movement } \\
\text { Integration }\end{array}$ & $\begin{array}{l}\text { The feeling of vacuum flow occurs as a result of } \\
\text { movement and integration between internal and external } \\
\text { spaces, and it is linked to the openings of doors, windows } \\
\text { and the style of design and relations between them } \\
\text { through the intermediate spaces with the desired safety } \\
\text { of the patient, which gives him the reassurance that } \\
\text { enables his movement and the integration of spaces, as } \\
\text { the movement is indirectly hidden from the contradiction } \\
\text { between some elements of functional or aesthetic design }\end{array}$ & $\begin{array}{l}\text { The flow of space (leakage of } \\
\text { space) helps to speed the } \\
\text { patient's gradual integration with } \\
\text { the extemal society with its } \\
\text { elementary elements within the } \\
\text { hospital in preparation for } \\
\text { integration with the whole real } \\
\text { external society, giving the } \\
\text { indirect movement a sense of } \\
\text { visual satisfaction resulting from } \\
\text { the change }\end{array}$ \\
\hline 6 & Stillness & $\begin{array}{l}\text { The static vacuum represents the protected environment that } \\
\text { gives the patient a sense of security and reassurance that he } \\
\text { needs in-some diseases need the severe insurance of the } \\
\text { patients themselves and here there must be the flexibility of the } \\
\text { complete closure secured openings. }\end{array}$ & $\begin{array}{l}\text { The paticnt needs an exchange } \\
\text { betwen stillness and movement, } \\
\text { which helps in the treatment and } \\
\text { the return to normal (the } \\
\text { condition of closure is not } \\
\text { required) }\end{array}$ \\
\hline$\Leftrightarrow$ & Functional & $\begin{array}{l}\text { Every vacuum in the hospital must achieve the full function of } \\
\text { different spaces, especially the spaces of treatment and } \\
\text { residence, by achieving all the correct conditions and standards } \\
\text { and the use of materials and appliances with the achievement of } \\
\text { human comfort (freedom, light, color, ventilation) and (social } \\
\text { and osvchological and Phvsical) }\end{array}$ & $\begin{array}{l}\text { The patient needs the } \\
\text { vacuum to be fully realized } \\
\text { in order to ensure the } \\
\text { treatment process and then } \\
\text { to recover }\end{array}$ \\
\hline & Containment & $\begin{array}{l}\text { The containment and assimilation of the patient's vacuum } \\
\text { is produced as an inevitable consequence of achieving this } \\
\text { vacuum for its function and ease of practicing the user in } \\
\text { activities in a suitable climate for it. }\end{array}$ & $\begin{array}{l}\text { Containment of the paticnt helps } \\
\text { to provide a good relationship } \\
\text { between him and the vacuum, } \\
\text { which is the beginning of } \\
\text { treatment and then reaching } \\
\text { healing }\end{array}$ \\
\hline 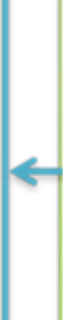 & $\begin{array}{l}\text { The personal } \\
\text { identity of the } \\
\text { vacuum }\end{array}$ & $\begin{array}{l}\text { When the patient reaches the highest levels of safety and reassurance } \\
\text { and communication with the achievement of the maximum aitable to } \\
\text { practice the activity in accordance with the needs of the patient so that } \\
\text { this void fills all the needs of the patient in a manner that fits with his } \\
\text { behavior } \$ \text { that the patient rea dhes the feeling that this hospital has } \\
\text { become a place and a spedal scientist that atits him and with His } \\
\text { qualities and lifexyle and his illness and full ness of all his needs will be } \\
\text { readhed this void phase the personal vacutm (the void with the personal } \\
\text { identity of the patient) }\end{array}$ & $\begin{array}{l}\text { Reaching the level of the patient's } \\
\text { personal emptiness represents the } \\
\text { real tarting point of treatment and } \\
\text { the opposite is the feeling of } \\
\text { alienation and awe, which affects } \\
\text { the process of treatmentto top and } \\
\text { may have the opposite effect }\end{array}$ \\
\hline & & $\begin{array}{c}\text { Human full awareness } \\
\text { of the vacuum }\end{array}$ & $\begin{array}{l}\text { e beginning of treatment } \\
\text { he path of healing }\end{array}$ \\
\hline
\end{tabular}

Chart (3) Concepts and vocabulary of the language of dialogue between the patient and the vacuum

(Designed by researcher) 


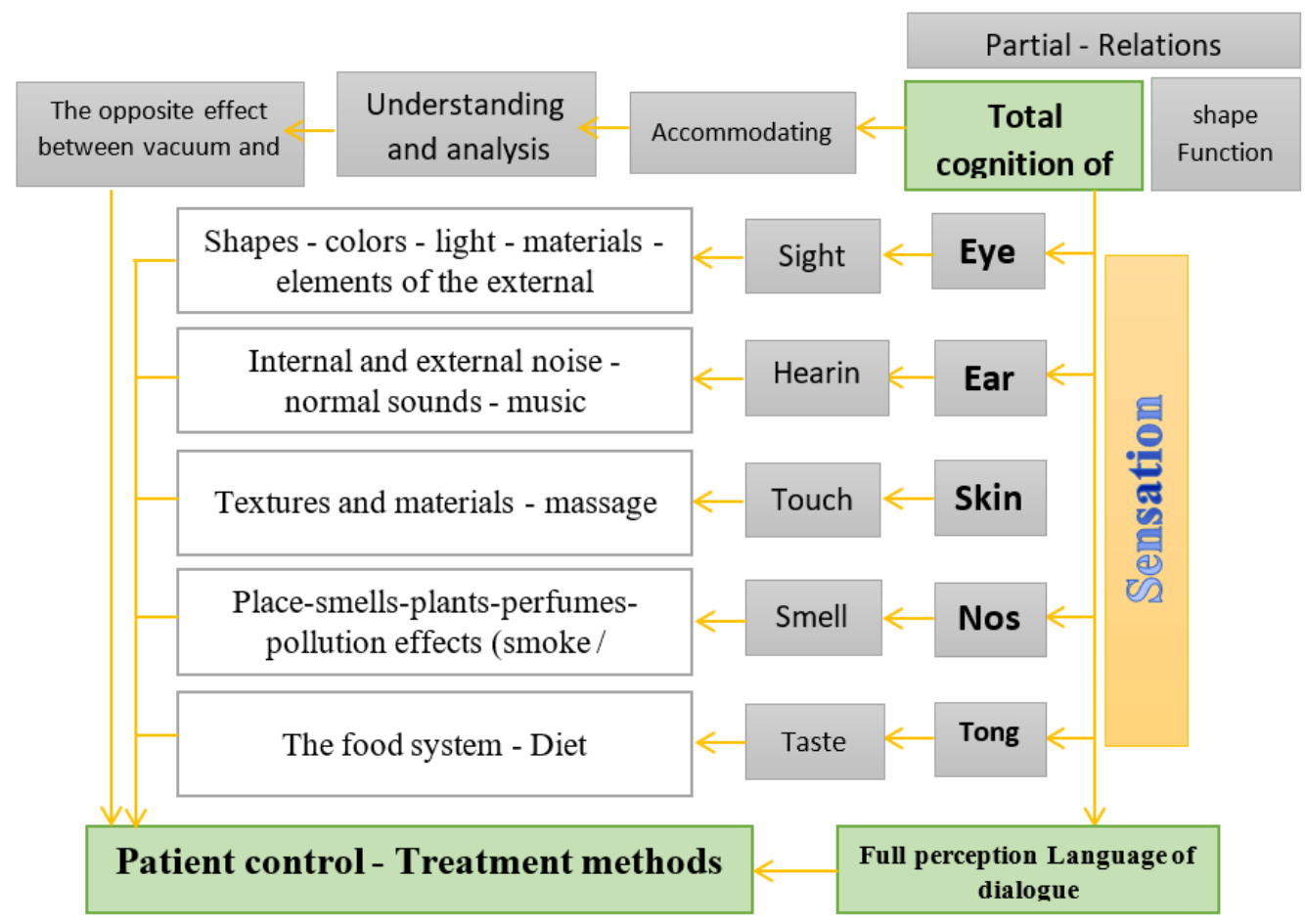

Chart (4) The five senses perception process (Designed by researcher)

Through the study of the full of these physical and sensory perceptions and their different effects on the patient, the designer is able to reach the correct internal design, which helps in the process of treatment (the study is limited to research on the perceptions of sight, hearing and touch) the resident psychiatric patient for treatment within the hospital needs me The personal space that the right individual needs to be fully aware and perform full functions (which must be provided to ensure the patient's desire to stay in place and treatment is an important step on the path of psychotherapy, and there are types of diseases need to reduce the spaces and freedoms of the patients at the beginning of treatment and With improvement allows to adjust the personal space for the better ) with the right security and safety for each disease while providing the required privacy and flexibility.

The process of perception takes place in certain steps until the mental and sensory perception is fully realized, the presence of stimuli (sensations) which make up the world of perceptions and senses, which are the means of man in the perception of these stimuli the presence of the central spinal brain nervous system (brain Brian), which in turn transmits the perceptatic to a meaningful realization of the existence of a record of accumulated experiences in the human which allows the nervous system to transmit the senses and classify them based on these experiences to perceptions, and without this record of experiences the nervous system cannot give meaning to the senses to become aware, the natural human (sui) realizes from The surrounding environment around it is what a person with a mental disorder or a person with mental disorder and vice versa, i.e. what a person who is mentally disturbed or mentally disturbed is not aware of, for example, the schizophrenic patient (or mental disorder) smells that do not exist and hears voices that do not exist. It has (auditory and visual hallucinations) as well as visual stimuli that do not already exist (visual hallucinations).

\subsubsection{Study of visual perceptions effects on the men-} tal patient:

Visual perception occurs by the fall of light on objects, the process of vision of the eye occurs and helps in the path of visual perception the movement of the head to cover a wider field of visual vision and the movement of the body and the quality and intensity of the lighting used, and includes visual perceptions all that the human sees inside the void and varies between Shapes, sizes, colors, ores and other elements such as plant and water, visual perception occurs completely and then the details are discovered successively in fact the patient realizes the void and affects him completely and when the period of survival increases in emptiness and looking and scrutinizing the details occurs full visual perception and Full effect. 


\begin{tabular}{|c|c|c|c|}
\hline \multicolumn{2}{|c|}{ Visual perceptions } & \multicolumn{2}{|l|}{ The effect } \\
\hline Lines & $\begin{array}{l}\text { Is the first determinant } \\
\text { of the perception of the } \\
\text { identification of shapes } \\
\text { and sizes (partial } \\
\text { perception) by } \\
\text { separating the areas and } \\
\text { shapes }\end{array}$ & $\begin{array}{l}\text { The patient begins to partially perceive the } \\
\text { vacuum of lines and hence the importance } \\
\text { of their psychological effects, horizontal } \\
\text { lines always suggest stability, calmness } \\
\text { and formality while vertical lines give a } \\
\text { sense of stability and slant give a sense of } \\
\text { movement and curved always give a sense } \\
\text { of softness and Softness, continuity and } \\
\text { interruption suggest vitality and } \\
\text { interaction. (18) relation between spaces } \\
\text { must be clear to the patient while } \\
\text { balancing the use of lines for comfort, } \\
\text { movement and calm. }\end{array}$ & $\begin{array}{l}\text { Image (1) The use of straight lines } \\
\text { with curved in a way that gives a } \\
\text { sense of design (Gundern Mental } \\
\text { Health Hospital). }\end{array}$ \\
\hline $\begin{array}{l}\text { Shap } \\
\text { e }\end{array}$ & $\begin{array}{l}\text { These are the basic } \\
\text { components of the } \\
\text { visual architectural } \\
\text { composition and are a } \\
\text { tool for organizing the } \\
\text { design content of the } \\
\text { emptiness, it restricts } \\
\text { the boundaries of space } \\
\text { and separation of blocks } \\
\text { and the inventory of } \\
\text { color areas and } \\
\text { materials, leading to the } \\
\text { full realization of } \\
\text { shapes and volumes and } \\
\text { their use and function in } \\
\text { space. }\end{array}$ & $\begin{array}{l}\text { For forms affecting the mind and reactions } \\
\text { and the psychological and mental state of } \\
\text { the patient, forms with straight lines and } \\
\text { existing angles give a sense of security, } \\
\text { strength, discipline and confidence while } \\
\text { the triangles are considered DNA forms } \\
\text { linked to the upper movement, and } \\
\text { determines the direction of the triangle and } \\
\text { the angles of the effects The psychology } \\
\text { that occurs, the existing triangle suggests } \\
\text { stability and formality, while the equal } \\
\text { ribs and legs suggest a pivotal movement, } \\
\text { while it is not preferable to use the } \\
\text { inverted triangle because it suggests } \\
\text { anxiety and tension, it is a form that } \\
\text { suggests danger, while it is preferable to } \\
\text { use circles because they suggest eternity } \\
\text { and immortality ( The sun and the orbits of } \\
\text { the planets) should also be used with } \\
\text { caution, which include: geometric shapes, } \\
\text { natural or abstract forms and reference }\end{array}$ & $\begin{array}{l}\text { Image (2) Use of rectangular } \\
\text { shape in the design of the } \\
\text { residence room for the patient }\end{array}$ \\
\hline
\end{tabular}




\begin{tabular}{|c|c|c|c|}
\hline & & $\begin{array}{l}\text { forms of heritage are overlapping forms of } \\
\text { meanings and insinuations and may cause } \\
\text { confusion in the therapeutic process, } \\
\text { simplicity, clarity and formal directness of } \\
\text { The most important features of the } \\
\text { appropriate vacuum for the mental patient. }\end{array}$ & $\begin{array}{l}\text { Image (3) Use the triangular shape } \\
\text { in the appropriate color in the } \\
\text { nursing station between rooms }\end{array}$ \\
\hline Light & $\begin{array}{l}\text { It is the basic element in } \\
\text { the process of visual } \\
\text { perception as it emits } \\
\text { the electromagnetic } \\
\text { radiation necessary for } \\
\text { vision and perception } \\
\text { and without it cannot be } \\
\text { completed and cannot } \\
\text { be carried out activity in } \\
\text { the vacuum, and } \\
\text { maintains the sight and } \\
\text { human comfort in } \\
\text { emptiness and achieving } \\
\text { public safety. are } \\
\text { Shadow areas are } \\
\text { produced as result of } \\
\text { the absence of light, } \\
\text { interference and } \\
\text { intersections resulting } \\
\text { from the intensity of } \\
\text { light, which help to } \\
\text { successfully complete } \\
\text { the visual perception } \\
\text { process where the } \\
\text { shadow shows shapes, } \\
\text { blocks, colors and } \\
\text { materials. }\end{array}$ & $\begin{array}{l}\text { The psychological effects of light are due } \\
\text { to the intensity of light, its strength, its } \\
\text { color, the nature of activity, the quality } \\
\text { and nature of the individuals and the } \\
\text { nature of the vacuum, in addition to the } \\
\text { method of distribution and the quality of } \\
\text { the lighting units used, and the light } \\
\text { affects the pineal gland that secretes the } \\
\text { hormone melatonin, which is inversely } \\
\text { related to light, the less The higher the } \\
\text { hormone and the more the body, the more } \\
\text { it is, the more depressed and depressed the } \\
\text { body is. } \\
\text { Natural lighting is the source of the sun } \\
\text { and varies depending on the geographical } \\
\text { location and time, and it is directly from } \\
\text { the openings or indirectly that pass } \\
\text { through the glass and curtains or reflected } \\
\text { from the external facades and floors, and } \\
\text { helps to flow the circulation of blood } \\
\text { wieces have different composition, } \\
\text { geometric or organic treadmill } \\
\text { and therefore the shadows should be } \\
\text { of the human (succession of lighting } \\
\text { between night and day) and her psychotic } \\
\text { signs are positive for the patients and on } \\
\text { the treatment process. } \\
\text { Industrial lighting with its various sources } \\
\text { has negative psychological and physical } \\
\text { effects on patients when they are not done } \\
\text { in a thoughtful way or when staying there } \\
\text { for long periods and color light also has } \\
\text { effects and is therefore considered one of } \\
\text { the methods of assistance in treatment } \\
\text { (Table 5)The presence of shadows helps to } \\
\text { improve the psychological state to } \\
\text { complete the process of visual perceptual } \\
\text { andirectly, and can negatively affect fear } \\
\text { and on patients suffering from }\end{array}$ & $\begin{array}{l}\text { Image (4) Combining natural } \\
\text { lighting with the use of } \\
\text { appropriate shapes and colors to } \\
\text { provide the right atmosphere for } \\
\text { the patient. } \\
\text { Image (5) The effect of lighting } \\
\text { and shadows on the } \\
\text { accommodation vacuum for the } \\
\text { patient }\end{array}$ \\
\hline
\end{tabular}




\begin{tabular}{|c|c|c|c|}
\hline & & $\begin{array}{l}\text { formations). (19) } \\
\text { Light therapy (uv radiation) a ffects b rain } \\
\text { chemicals associated with mood and sleep, } \\
\text { helping to treat sleep disorders, depression } \\
\text { and dementia. }\end{array}$ & $\begin{array}{l}\text { Image (6) Industrial integration of } \\
\text { the external e nvironment } \mathrm{w} \text { ith } \\
\text { indirect light in the screening and } \\
x \text {-ray } r \text { ooms } \mathrm{o} \text { reduce } \mathrm{p} \text { atient } \\
\text { tension. }\end{array}$ \\
\hline $\begin{array}{l}\text { Colo } \\
\mathrm{r}\end{array}$ & $\begin{array}{l}\text { It is a sensory } \\
\text { perception that has } \\
\text { symbolic, emotional, } \\
\text { physical and } \\
\text { psychological effects } \\
\text { and is one of the most } \\
\text { consistent visual } \\
\text { languages, receiving } \\
\text { visual stimulation and } \\
\text { processing and reactive } \\
\text { response representing } \\
\text { the components of color } \\
\text { work, balance, rhythm } \\
\text { and movement of color } \\
\text { that represent elements } \\
\text { of the visual-chromatic } \\
\text { language perceptions. }\end{array}$ & $\begin{array}{l}\text { The effects } \\
\text { emotional/psychological/physical/symboli } \\
\text { c) of colors lead to positive or negative } \\
\text { reactions, and this feeling must be } \\
\text { simulated through design so that the colors } \\
\text { commensurate with each vacuum in the } \\
\text { psychiatric hospital are chosen from the } \\
\text { functional side according to the function } \\
\text { of each vacuum and the characteristics of } \\
\text { the color and the resulting psychological } \\
\text { and physical reactions affecting the patient } \\
\text { and the treatment process described in } \\
\text { Table } 3 . \\
\text { It is also necessary to study the } \\
\text { psychology of colors and the method of } \\
\text { psychotherapy in color and art and study } \\
\text { various psychiatric diseases } \\
\text { (symptoms/treatment methods) in order to } \\
\text { determine the appropriate colors for use } \\
\text { for each disease and described examples in } \\
\text { (Table 4). (20) and (21) }\end{array}$ & $\begin{array}{l}\text { Image (7) Use cold a nd } n \text { eutral } \\
\text { colors } t o \text { help } t \text { he } p \text { atient } c \text { alm } \\
\text { down, relax and sleep }\end{array}$ \\
\hline $\begin{array}{l}\text { Wate } \\
\mathbf{r}\end{array}$ & $\begin{array}{l}\text { Water is the s ecret of } \\
\text { life and a source o f } \\
\text { safety a nd s tability } \\
\text { (since a ncient } \mathrm{t} \text { imes } \\
\text { man settles } \mathrm{n} \text { ext to } \\
\text { water). }\end{array}$ & $\begin{array}{l}\text { Fixed } \mathrm{w} \text { ater ( static) represents calm, } \\
\text { stability a nd s afety and gives a vertical } \\
\text { extension and continuity o f space } \\
\text { (reflecting like an inverted mirror). } \\
\text { Running water (moving) is a source of } \\
\text { movement a nd a ctivity and reduces the } \\
\text { patient's sense of boredom, monotony and } \\
\text { sadness and raises } m \text { orale due to t he } \\
\text { feeling of continuous and renewed life. } \\
\text { The general feeling of peace, reassurance } \\
\text { and pleasure resulting from the feeling of } \\
\text { water beauty as well as the hydration and }\end{array}$ & 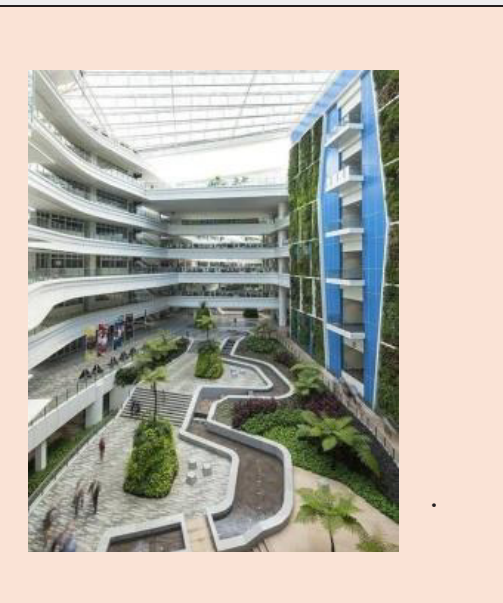 \\
\hline
\end{tabular}




\begin{tabular}{|c|c|c|c|}
\hline & & purification of the air. & $\begin{array}{l}\text { Image }(8) \text { The use of water in the } \\
\text { inner courtyard to create an area } \\
\text { that represents the external } \\
\text { environment inside the hospital } \\
\text { for more safety and control of the } \\
\text { disease. }\end{array}$ \\
\hline plant & $\begin{array}{l}\text { The plant inside the } \\
\text { vacuum is a microcosm } \\
\text { of the natural } \\
\text { environment in its } \\
\text { natural form or } \\
\text { simulated } \\
\text { photographs. }\end{array}$ & $\begin{array}{l}\text { Gives the patient a sense of comfort and } \\
\text { calm with the availability of pure air free } \\
\text { of pollutants, which is known as the } \\
\text { healthy environmental impact of the plant, } \\
\text { which helps to relax and reduce pressures } \\
\text { and give a sense of spirit and life and thus } \\
\text { a hidden sense of joy, as well as visual } \\
\text { importance in the temporal perception of } \\
\text { what happens to him A quarterly change. }\end{array}$ & $\begin{array}{l}\text { Image (9) The use of the plant } \\
\text { inside the vacuum gives the } \\
\text { patient a sense of calm and } \\
\text { relaxation. }\end{array}$ \\
\hline $\begin{array}{l}\text { Outd } \\
\text { oor } \\
\text { envir } \\
\text { onm } \\
\text { ent } \\
\text { (ope } \\
\text { n } \\
\text { spac } \\
\text { es) }\end{array}$ & $\begin{array}{l}\text { The interior spaces are } \\
\text { integrated with the } \\
\text { external environment, } \\
\text { including green areas } \\
\text { and sky, and may reach } \\
\text { an area of up to } 75 \% \text { of } \\
\text { the total area of the } \\
\text { psychiatric hospital. } \\
\text { The mutual and } \\
\text { interactive relationship } \\
\text { between the internal and } \\
\text { external vacuum creates } \\
\text { a state of visual } \\
\text { harmony and reduces } \\
\text { closure and helps to } \\
\text { integrate, it is an } \\
\text { important factor in the } \\
\text { therapeutic process. }\end{array}$ & $\begin{array}{l}\text { Open green spaces improve physical } \\
\text { health because it reduces muscle blood } \\
\text { pressure because it reduces pollution, dust } \\
\text { and temperatures and increases shading. } \\
\text { It also works to improve the mental health } \\
\text { of patients because it provides calm and } \\
\text { rest and reduces depression, fear, anger } \\
\text { and stress, helps patients meditate, think } \\
\text { and concentrate, increase self-esteem and } \\
\text { reduce stress and thus decrease the rates of } \\
\text { violence, vandalism and crime. } \\
\text { Providing security, privacy and integration } \\
\text { between open and internal external spaces } \\
\text { (With appropriate monitoring for each } \\
\text { patient according to illness), the patient is } \\
\text { granted communication and out of } \\
\text { isolation and gradual integration into } \\
\text { society. ( } 21 \text { ) }\end{array}$ & $\begin{array}{l}\text { Photos (10) Provide an open } \\
\text { external environment to improve } \\
\text { physical and mental health. }\end{array}$ \\
\hline
\end{tabular}

Table (3) Effects of visual perceptions on the mental patient (Designed by researcher) 


\begin{tabular}{|c|c|c|}
\hline Mental illness & $\begin{array}{l}\text { suitable Colors for use in } \\
\text { medical accommodation }\end{array}$ & Reason for use \\
\hline $\begin{array}{l}\text { Memory } \\
\text { impairment }\end{array}$ & Yellow & A brain-thinking cell tonic and mental disability. \\
\hline Insomnia - Anxiety & Blue + white & $\begin{array}{l}\text { Reduces insomnia and helps to flush out whispers } \\
\text { and overcome uncertainty. }\end{array}$ \\
\hline Depression & \begin{tabular}{lrr}
\multicolumn{2}{l}{ Predominant blue +} \\
$\begin{array}{l}\text { orange (in } \\
\text { proportions) }\end{array}$ & &
\end{tabular} & $\begin{array}{l}\text { Blue: Expels authoritarian ideas and reduces } \\
\text { pessimism. } \\
\text { Orange: Stimulates movement and gives a sense of } \\
\text { fun and anti-frustration and depression and facilitates } \\
\text { digestion. }\end{array}$ \\
\hline $\begin{array}{l}\text { Nervous agitation - } \\
\text { violence }\end{array}$ & $\begin{array}{l}\text { Predominantly light blue } \\
+ \text { purple }\end{array}$ & $\begin{array}{l}\text { Light Blue: Calming over-the-hand, it is a cool and } \\
\text { calm color that calms excess nervousness, treats high } \\
\text { blood pressure, reduces stress and increases } \\
\text { reassurance. } \\
\text { Violet: General sedative for neurological and } \\
\text { psychological diseases. }\end{array}$ \\
\hline $\begin{array}{l}\text { The tendency } \\
\text { hurt oneself } \\
\text { others. } \\
\text { other }\end{array}$ & Indigo blue + green & $\begin{array}{l}\text { Indigo Blue: Cures mental disorders. } \\
\text { Green: Nature's calm color is a passion for mercy, } \\
\text { complementing the red color (blood) that helps the } \\
\text { patient to control his actions. }\end{array}$ \\
\hline $\begin{array}{l}\text { Acute or chronic } \\
\text { schizophrenia - } \\
\text { Paranoia }\end{array}$ & $\begin{array}{l}\text { Predominant green }+ \\
\text { orange }+ \text { brown (in small } \\
\text { proportions) }\end{array}$ & $\begin{array}{l}\text { Green: Helps to regulate the soul and body and } \\
\text { control emotions and because it is the color of nature } \\
\text { helps the patient to return to normal and get rid of the } \\
\text { disease. } \\
\text { Orange: It excites the patient and helps strengthen } \\
\text { social relationships, which helps him to get out of the } \\
\text { illusion and fantasies and engage with the } \\
\text { community. } \\
\text { Brown (in small proportions) gives a sense of } \\
\text { strength to the patient stemming from his self- } \\
\text { reliance and thus gives him a sense of security. }\end{array}$ \\
\hline Hysteria & $\begin{array}{l}\text { Mostly green }+ \text { (orange }+ \\
\text { blue) in small proportions }\end{array}$ & $\begin{array}{l}\text { Green: The color of nature helps the patient to return } \\
\text { to normal and calm blue: a cool and calm color } \\
\text { reduces the pulse rate and body temperature helps the } \\
\text { patient to get out of cases of increased emotional } \\
\text { pressure and helps him to be a balanced person. } \\
\text { Orange: Urges the patient to feel fun and warm and } \\
\text { get rid of the symptoms of the disease. }\end{array}$ \\
\hline The fear & White + blue & $\begin{array}{l}\text { White: A color that suggests calm, purity and clarity } \\
\text { (the patient sees everything and no ambiguity) and } \\
\text { gives the patient the sense of safety that he needs to } \\
\text { overcome his fears. } \\
\text { Blue: A calm color helps the patient to relax and rest } \\
\text { and helps him to expel doubt and whispers. }\end{array}$ \\
\hline
\end{tabular}

Table (4) Some examples of mental illnesses and appropriate colors and their psychological effects on patients (2), (20), (22) and (23) (Designed by researcher) 


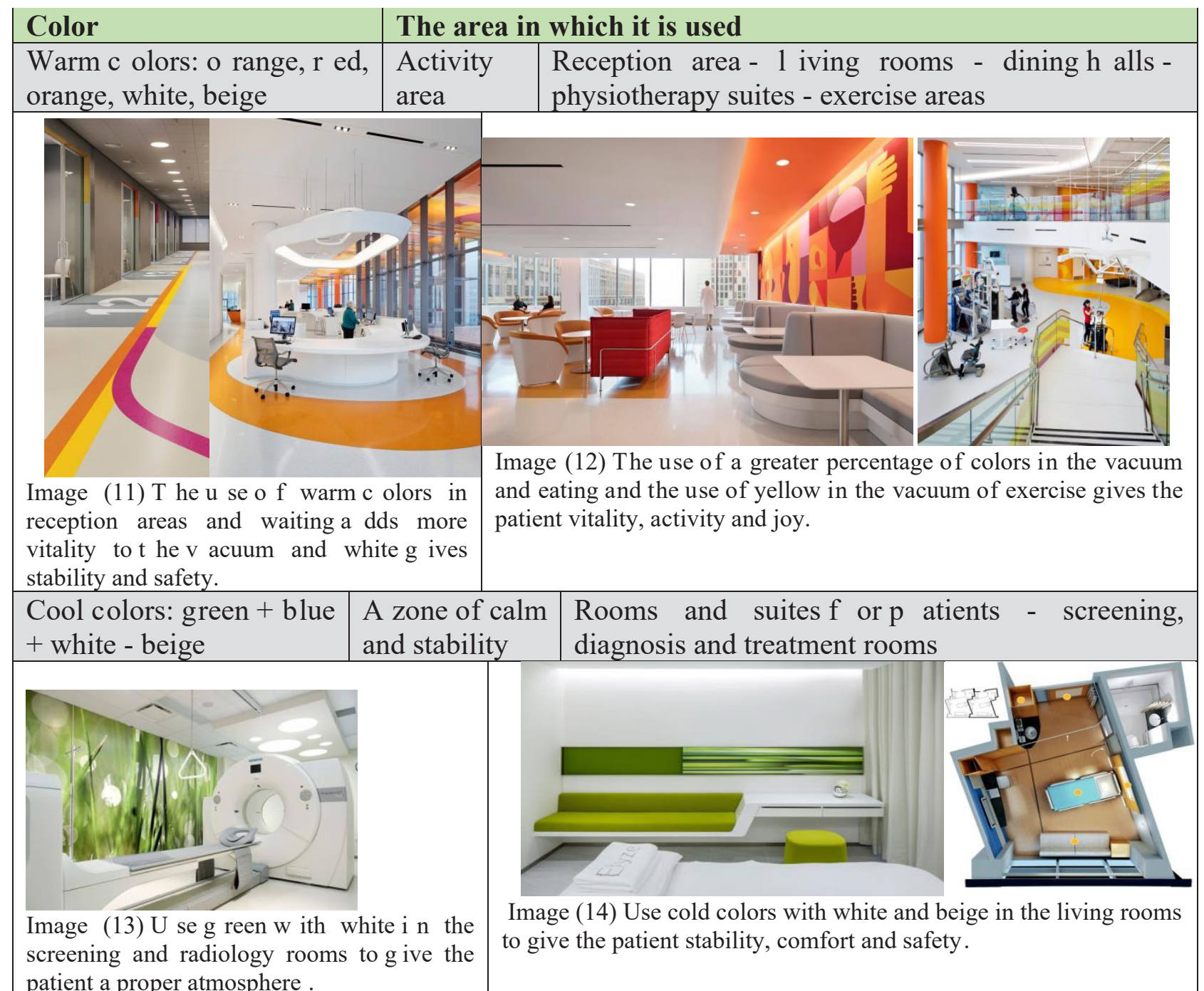

Table (5) a ppropriate $\mathrm{c}$ olors for use in different s paces in the $\mathrm{h}$ ospital and its psychological e ffects o $\mathrm{n}$ patients

(Designed by researcher)

\subsubsection{Studying the effects of auditory perceptions on} the mental patient:

The patient completes the awareness of the mental image of the vacuum through sounds and the psychiatric hospital building is considered a complex spaces that need to make studies and sound simulations of architectural and interior design, it contains a large number of different activities that must be observed coordination between them vocally, and includes sound By emptying the sounds resulting from the practice of activities and their follow-up and intensity and dialogue between people and the voices of patients (some pathological conditions are accompanied by screaming, shouting or crying or imagining talking to people....) and the sounds of all the devices contained in the vacuum (medical devices - telephones - air con- ditioners - fans.....) and sounds Service areas that are part of the internal noise as well as the external light coming from outside the building.

In order to reach the correct acoustic perception of the patient, the vacuum must be achieved by:

- Isolating noise of both types because of its damage it affects the nervous system and raises blood pressure and disorders of the organs of the body and increases stress, anxiety and depression.

- External noise is isolated by choosing the right location for the building (in relatively quiet areas away from dense noise areas such as train stations and airports) with the use of plants and trees, while internal noise is isolated by vacuum insulation in the sense of dividing spaces according to what It results from internal noise (for example, accommodation spaces 
should not be close to directly or indirectly from the hospital reception space) and also by using acoustic insulation cladding in all interior design and furniture elements.

- The sound studies of all the spaces are separate and continuous and include the study of different types of sounds and the sound rays of them and the sand and the temporal until the vacuum becomes achieved for acoustic comfort.

- Study of the formations, materials and contact suppall used from the acoustic point of view (reflections - absorption - dispersion) and their different psychological effects on patients described in table (6). (24) Music: Is a kind of fine arts that improve the mood, physical and psychological of the patient, the use of the appropriate music according to each disease increases the moral state because of its simple and accurate effects but it is very important and that can affect the therapeutic process negatively or positive- ly, mouth The music reception in the brain interferes with the centers of emotion and here the language can be treated so that it is useful in cases of dementia or provokes memories and helps in diseases of memory impairment.

Music helps to improve many psychological conditions such as depression, dementia, weakness and memory disorder, schizophrenia, autism, addiction and insomnia because it helps to calm down, focus and express feelings (some conditions can not express themselves using words and here can become Music is a language that expresses its ideas, enhances memory, improves mood, improves social communication, and music therapy is an interactive treatment between the patient, which must have the desire and willingness to do so and between music in the form of listening, playing and singing activities practiced by the patient. In the presence of a specialist. (25), (26) and (27)

\begin{tabular}{|c|c|c|}
\hline $\begin{array}{l}\text { Elements of } \\
\text { interior } \\
\text { design }\end{array}$ & The kind. & The effect. \\
\hline \multirow[t]{3}{*}{ Walls } & $\begin{array}{l}\text { Increased formations - rough contact - } \\
\text { dispersed materials }\end{array}$ & \multirow{2}{*}{$\begin{array}{l}\text { It has a negative psychological effect from the internal } \\
\text { noise raising. }\end{array}$} \\
\hline & $\begin{array}{l}\text { Lack of formations - soft contact - } \\
\text { reflective materials }\end{array}$ & \\
\hline & Use of sound absorbents & $\begin{array}{l}\text { Helps to control the vocal vacuum and reduce noise and } \\
\text { calm and thus effect the psychological comfort of the } \\
\text { patient. }\end{array}$ \\
\hline \multirow[t]{2}{*}{ Floors } & Use polished floors & $\begin{array}{l}\text { It has a negative psychological effect from the internal } \\
\text { noise raising. }\end{array}$ \\
\hline & Use of sound absorbent floors (e.g. cork) & $\begin{array}{l}\text { It has a psychological effect with the comfort of reducing } \\
\text { the sound of human movement that causes vibrations. }\end{array}$ \\
\hline \multirow[t]{3}{*}{ Ceiling } & $\begin{array}{l}\text { Flat, sound-reflective or polished } \\
\text { ceilings }\end{array}$ & $\begin{array}{l}\text { It has a negative psychological effect from the internal } \\
\text { noise raising. }\end{array}$ \\
\hline & Sound-absorbing flat ceilings & $\begin{array}{l}\text { It is the right quality for use in the psychiatric hospital } \\
\text { because of its good psychological impact resulting from } \\
\text { sound control and noise reduction. }\end{array}$ \\
\hline & Oblique or vaulted ceilings & Partially used with flat ceilings. \\
\hline \multirow[t]{2}{*}{ Furniture } & $\begin{array}{l}\text { Distribution of furniture helps distract } \\
\text { the sound }\end{array}$ & \multirow[t]{2}{*}{$\begin{array}{l}\text { Helps reduce noise and calm, making an impact on the } \\
\text { mental well-being of the patient. }\end{array}$} \\
\hline & $\begin{array}{l}\text { Sound absorbent materials used in } \\
\text { furniture. }\end{array}$ & \\
\hline
\end{tabular}

Table (6) audio-appropriate configurations for use in different spaces in the hospital and its psychological effects on patients (Designed by researcher)

2.3.3. Study the effects of tactile perceptions on the mental patient:

Texture: One element of formation and touch is the feeling of these elements directly or the visual experience of the materials and is a two-dimensional representation and it is difficult to separate the materi- als and contact them and light and color where light plays an important role without it will not show areas of light and shadow that show the texture of the materials Different and employed of different types to suit the vacuum, patients and activity as it must vary in the use of different contacts to achieve the contrast 
of the void, and the texture is present in all the void inside and out on the patient and the different contact and its effects and shows the table (7) different contact and Its psychological effects on patients.

Raw materials: The world of interior design materials and furniture is endless and is an essential element in the formation integrated the process of general perception of space and visual and tactile perception may precede other elements such as color and light, and the modern materials contribute to the creation of spaces more suitable for the activities of the psychiatric hospital and the nature of the Satisfactory nanotechnologies contributed to the creation of clean spaces through self-cleaning paints and antifungal glass and bacteria, and smart and digital materials contributed to more flexibility and control of the vac- uum in terms of sound, color and light in proportion to the nature of individual patients cases Their diseases, in general, must comply with the international specifications for the use of materials in hospitals.

- The use of natural materials (such as wood, stone and glass) that give the patient a sense of comfort and serenity.

- The use of sound absorbent materials to provide acoustic comfort in the vacuum to provide psychological comfort and calm, which contributes to the treatment process.

- The use of unstudied manufactured materials may lead to physical or physical damage from their role that negatively affects the patient's psyche and the treatment process.

\begin{tabular}{|c|c|c|c|c|}
\hline \multicolumn{2}{|c|}{ Texture Type } & Psychological effects & \multicolumn{2}{|c|}{ Appropriate Vacuum } \\
\hline \multirow[t]{2}{*}{ Class } & Pretty & $\begin{array}{l}\text { It gives the patient a sense } \\
\text { of calm and relaxation, it } \\
\text { reduces detail and shadows, } \\
\text { suggests dilation, reduces } \\
\text { stress and helps to relax. }\end{array}$ & $\begin{array}{l}\text { Accommodation } \\
\text { and treatment } \\
\text { vacuum }\end{array}$ & 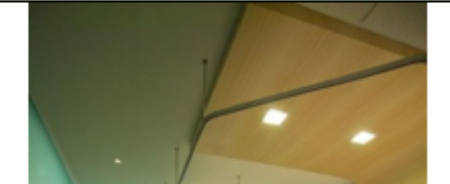 \\
\hline & Rough & $\begin{array}{l}\text { It suggests movement and } \\
\text { increases with shadows. }\end{array}$ & $\begin{array}{l}\text { Motor vacuum } \\
\text { such as physical } \\
\text { therapy vacuum or } \\
\text { exercise }\end{array}$ & \\
\hline \multirow[t]{2}{*}{$\begin{array}{l}\text { Appearan } \\
\text { ce }\end{array}$} & Regular & $\begin{array}{l}\text { Gives a sense of formality } \\
\text { and regularity. }\end{array}$ & Reception space & \\
\hline & Irregular & $\begin{array}{l}\text { Gives a sense of } \\
\text { randomness and movement }\end{array}$ & $\begin{array}{l}\text { Can be used very } \\
\text { carefully in } \\
\text { exercise spaces }\end{array}$ & \\
\hline \multirow[t]{4}{*}{ Type } & Real & $\begin{array}{l}\text { Contact that the patient can } \\
\text { feel for her spatial proximity } \\
\text { gives him a sense of desire } \\
\text { to explore and helps to } \\
\text { realize the mind and } \\
\text { remember and inspire } \\
\text { srightness and movement }\end{array}$ & $\begin{array}{l}\text { Part of the living } \\
\text { spaces and public } \\
\text { spaces }\end{array}$ & $\begin{array}{l}\text { Images (15) The calmness and } \\
\text { breadth resulting from the use of } \\
\text { soft contact with the space of }\end{array}$ \\
\hline & Not Real & $\begin{array}{l}\text { Unreal contact images or } \\
\text { images of landscapes or } \\
\text { places }\end{array}$ & $\begin{array}{l}\text { Public spaces such } \\
\text { as reception space } \\
\text { and nursing } \\
\text { stations }\end{array}$ & \\
\hline & Natural & $\begin{array}{l}\text { It's the texture of nature, like } \\
\text { the texture of the skin and } \\
\text { the glass, and it benefits the } \\
\text { patient in the sense that he } \\
\text { lives in a natural } \\
\text { atmosphere. }\end{array}$ & \multirow{2}{*}{$\begin{array}{l}\text { Taking into } \\
\text { account the use } \\
\text { according to the } \\
\text { type of vacuum, } \\
\text { activity and type of } \\
\text { disease }\end{array}$} & residence \\
\hline & Industrial & $\begin{array}{l}\text { From natural-like materials } \\
\text { and sometimes give a sense } \\
\text { of uneasiness and logical }\end{array}$ & & $\begin{array}{l}\text { Photo (16) } \\
\text { variety of contact between soft, } \\
\text { rough, natural and false in the } \\
\text { hospital reception space }\end{array}$ \\
\hline
\end{tabular}

Table (7) various contact and its psychological effects on patients (Designed by researcher) 


\section{- The results:}

1. Maintaining public physical and psychological health has a direct impact on the individual and society.

2. The internal design of psychological hospitals by applying the foundations of architectural psychology in the study of human beings, emptiness and different perceptions based on human and senses leads to obtaining internal spaces suitable for the psychological patient to help him stay in the hospital and treatment to the stage of healing.

\section{- Recommendations}

1. The research recommends opening the field towards the orientation of more research that studies how to take advantage of materials and modern technologies (nano- smart, digital, interactive ....) and apply their use within the different spaces of the psychiatric hospital to obtain the desired design flexibility to suit the vacuum with The patient and the patient, realizing the foundations of architectural psychology.

2. The research recommends that the different sectors of the country direct more research and construction efforts to the mental health sector because of its great importance to the individual and society.

3. The research recommends that a psychiatric therapeutic institution adopt the idea of researching the application of design using the foundations of architectural psychology (as an experimental design sample) to improve the therapeutic voids of mental illness.

\section{- References :}

1. WHO Guide (2002) \& (2017).

2. Dr. Hamed Abdel Salam Zahran, Mental Health and Physical Therapy, Book scientist, fourth edition, Egypt, p. 9 (2005).

3. Health Policy and Systems Program, Health Development and Environment Association, Health Status in Egypt, An Analytical Study of the Current Situation and Future Vision (2005).

4. World Health Report, (2000) \& (2017)

5. Eric Forum sees personality as a set of inherited and acquired psychological and physical traits that distinguish an individual's personality from being otherwise.

6. Louay Marhaj, The Design Foundations of Psychiatric Buildings, Ba'ath University Journal, Volume 36, Issue 6, p. 16 and 17, (2014).

7. Joseph De Chiara \& Michael J. Crosbi,1 TIME-SAVER STANDARDS for Building Types, Fourth Edition, McGraw Hill, Pg. 592( 608) (2005)

8. Maha Mahmoud Ibrahim, Mona Mahmoud Shamseddine, Emotional Design and Its Impact on Human Behavior in The Inner Spaces, 2nd International Conference of the Faculty of Applied Arts, Helwan University (2012).

9. Parisa Akbari, Hassan Saltarisarban Gholi, Architectural Design Based on Environmental Psychology Prespective, The Turkish online Journal uf Design art and Communication to JD, Special Edition, (July 2016).

10. Sussman, A,\& Hollander,J. B., Cognitive Architecture Design for How we Respond to the Built Enviroment, New York, Routledge, (2015).

11. Abdul Rahman Mohammed Issawi, Environmental Psychology, Alexandria Knowledge Facility, Egypt, (1997).

12. Abderrahmane Mohamed Issawi, Physiological Psychology (Study in the Interpretation of Human Behavior), University House of Knowledge, Egypt, (1989).

13. Seema Al-Channeli, The Role of The Void in Architectural Composition and Its Importance, Master's Thesis, Faculty of Architecture, Damascus University, (2015). 
14. Natali Ricci, The Psychological Impact of Achitectural Dresign, CMC Senior Theses, Claremont McKenna College, (2018).

15. Rania Mohammed Ali Taha, The Mutual Impact between the Urban Reality of Housing and the Socio-Cultural Identity of the Population (Study Case: Old City of Nablus), Master's Thesis, National University of Success, Graduate School, Palestine (2010).

16. Yasmine Seif, Interior Architecture of Children's Hospitals, Master's Thesis, Department of Decoration, Department of Interior Architecture, Faculty of Fine Arts, Helwan University, (2011).

17. Robert Gilam Scott, translation, Dr. Abdul Baqi Mohammed Ibrahim, Mohamed Mahmoud Youssef, Founder of Design, Renaissance House of Printing and Publishing.

18. https://tubikstudio.com/knock-design-intoshape-psychology-of-shapes/ (2019)

19. Rosella Tomassoni, Giuseppe Galetta, Eugeni Treglia, Psychology of Light: How Light Influences the Health and Psyche, (2015), https://www.researchgate.net/publication/280876651_Psychology_of_Light_How_ Light_Influences_the_Health_and_Psyche (2019)

20. Mustafa Shakib, Psychology of Colors: Psychological Effects of The Luan, Electronic Publishing House, www.kotobarabia.com

21. Heb-Talla Hmdy Mahmoud, Interior Architecture Elements that Affect Humman Psychology and Behavior, International Journal on:The Academic Reserch Commuity Publiction, The International Conference: cities Identity Through Architecture and Arts.

22. https://www.verywellmind.com/color-psychology-2795824 (Sept. 2019)

23. https://archinect.com/features/article/53292622/color-in-architecture-more-than-just-decoration

24. Allen, Edward, How Building work, Oxford Uinversity Press, Inc, 3 rd Edition, (2005)

25. https://www.skynewsarabia.com/technology/1174574- (Feb. 2020)

26. https://www.elconsolto.com/psychiatric/psychiatric-news/details/2018/7/22/1397127/
(Feb. 2020)

27. Aldridge, David, Music Therapy in Dementia Care, London Jessica Kingsley Publishers, (2000).

28. M. David Egan, Architectural Acoustics, McGraw, Hill Book Company, New York, United States of America, (1988)..

29. https://archinect.com/features/article/53292622/color-in-architecture-more-than-just-decoration(2019)

30. http://www.apex 1 design.com/?page $\mathrm{id}=48(2019)$

31. Flynn, J. E., The Psychology of Light, Orientation as a Visual Task, Electrical Consultant, (1973). 